\title{
HIV and Tuberculosis co-infection impacts T-cell activation markers but not the numbers subset of regulatory T-cells in HIV-1 infected patients
}

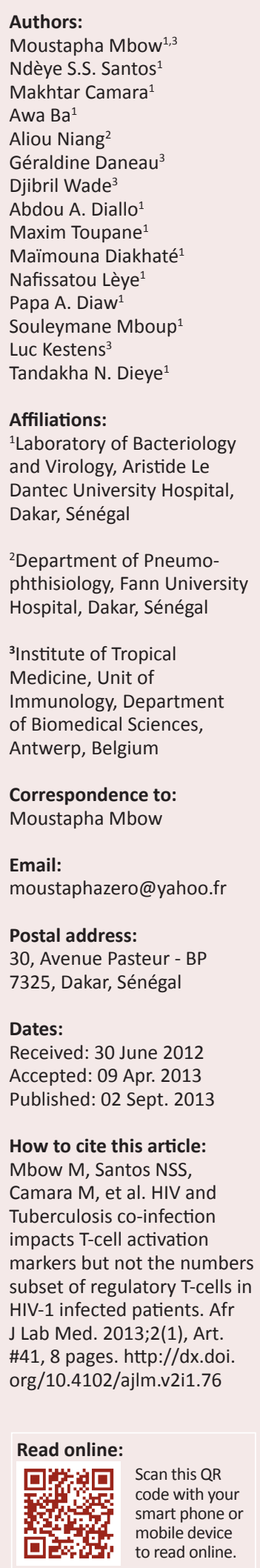

Authors

Awa Ba

Aliou Niang

raldine Danea

Abdou A. Dial

Maxim Toupane

Maïmouna Diakhate

Souleymane Mboup

Luc Kestens

Affiliations:

${ }^{1}$ Laboratory of Bacteriolog and Virology, Aristide Le

Dantec University Hospital,

phthisiology, Fann University

Hospital, Dakar, Sénégal

nstitute of Tropical

Medicine, Unit of

Correspondence to:

Email:

Postal address

30, Avenue Pasteur - BP

Dates:

Received: 30 June 2012

Accepted: 09 Apr. 2013

Published: 02 Sept. 2013

ow to cite this article:

Mbow M, Santos NSS,

ara $\mathrm{M}$, et al. HIV and

impacts T-cell activation

markers but not the numbers

subset of regulatory T-cells i

\#41, 8 pages. http://dx.do

org/10.4102/ajlm.v2i1.76

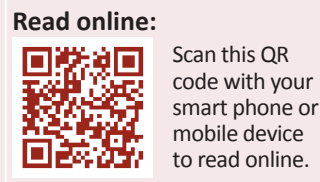

Background: Tuberculosis (TB) has been shown to accelerate the clinical course of HIV infection, but the mechanisms by which this occurs are not well understood. Regulatory T-cells (Tregs) are known to dampen hyperactivation of the immune cells, but it remains unclear whether hyperactivation of T-cells in HIV infection is associated with a decrease of Tregs and what the effect Mycobacterium tuberculosis (MTB) co-infection has on T-cell activation and Tregs.

Objectives: In this study, we aim to evaluate whether active TB is associated with the increased expression of T-cell activation markers and reduced number of Treg cells in HIV-1-infected patients.

Methods: This study was conducted on 69 subjects consisting of $20 \mathrm{HIV}$-infected patients, $20 \mathrm{HIV}$ and MTB co-infected patients, 19 MTB-infected patients and 10 uninfected control subjects negative for both MTB and HIV. The frequencies of T-cell activation markers (CD38 and HLA-DR) and Treg cells (CD4 $\left.{ }^{+} \mathrm{CD} 25^{+} \mathrm{CD} 127-\right)$ were measured by flow cytometry.

Results: Significantly higher expression of CD38 and HLA-DR on CD4 ${ }^{+}$and CD8 ${ }^{+}$T-cells was found in MTB and HIV co-infected patients compared with HIV-infected patients. However, no significant difference in the percentage of Treg cells was reported between HIV patients with TB and those without. The study also showed a negative correlation between regulatory $\mathrm{T}$-cells frequency and $\mathrm{CD} 4^{+} \mathrm{T}$-cell counts.

Conclusion: These results suggest that TB enhances the expression of peripheral T-cell activation markers during HIV infection, whilst having no impact on the percentages of Treg cells.

\section{Introduction}

HIV infection and tuberculosis (TB) are serious public health problems, especially in Africa. Coinfection with Mycobacterium tuberculosis (MTB) and HIV leads to alteration in the clinical course of both diseases. ${ }^{1}$ Since the 1990s, the global burden of TB has been markedly exacerbated by $\mathrm{HIV}$, which is one of the leading causes of the resurgence of TB in developed countries. ${ }^{2}$ Chronic activation, dysfunction of the immune system and loss of CD4 ${ }^{+} \mathrm{T}$-cells ${ }^{3}$ favour the emergence of active TB in HIV patients. ${ }^{4}$ Reciprocally, the immune response of the host to TB has been shown to increase HIV-1 replication ${ }^{4,5}$ and to accelerate the natural progression to AIDS. ${ }^{6,7}$ The proportional expression of the HLA-DR activation marker has been shown to increase in TB and/or HIV dualinfected patients as compared with TB single-infected patients. ${ }^{8}$ Today, TB remains one of the leading causes of death amongst HIV-positive patients. ${ }^{1}$

The mechanism by which TB accelerates the clinical course of HIV infection remains unclear. However, accumulating data suggest that T-cell activation in HIV-infected patients is a predictor for clinical disease progression ${ }^{9,10,11,12}$. CD38 and HLA-DR expression levels on CD4 ${ }^{+}$and CD8 ${ }^{+}$ T-cells, both markers of T-cell activation, are increased in HIV-infected patients and their levels of expression are associated with the HIV disease stage in untreated patients. ${ }^{13}$ Furthermore, elevated CD38 expression on CD8 ${ }^{+}$T-cells is a strong marker for the risk of chronic HIV disease progression to AIDS and, eventually, death. ${ }^{14}$ There is some evidence that aberrant immune activation, at least in part, leads to T-cell depletion through activation-induced cell death or enhanced HIV replication. ${ }^{15,16}$

Regulatory T-cells (Tregs) influence the outcome of various infections ${ }^{17}$ and have been shown to be involved in the regulation of the immune response during HIV infection. ${ }^{18,19}$ Whilst Tregs suppressing hyperactivation may slow disease progression, their expansion has been associated

Copyright: (C) 2013. The Authors. Licensee: AOSIS OpenJournals. This work is licensed under the Creative Commons Attribution License. 
with disease progression ${ }^{20,21}$ and a worsening of the immune deficiency that is characteristic of HIV infection. ${ }^{22,23,24}$ Several studies have reported conflicting results as levels of Treg cells were found to be unaffected, ${ }^{25}$ increased $^{26}$ or decreased ${ }^{27}$ with disease progression in HIV-infected patients. There is still controversy about $\mathrm{CD} 4^{+} \mathrm{CD} 25^{+} \mathrm{CD} 127^{\text {low/- }}$ and $\mathrm{CD} 4^{+} \mathrm{CD} 25^{+} \mathrm{FoxP}^{+}$identifying the same subset of Treg cells. Lui et al. suggested that they could be used interchangeably ${ }^{28}$ whilst Klein et al. stated that those subsets were not identical. ${ }^{29}$ However, other studies confirmed that both subsets can be used to identify Tregs. ${ }^{30,31,32}$

To our knowledge, there have been no previously-published studies regarding the issue of whether TB is associated with the expression of Treg cells in HIV-infected patients. This study aimed to investigate the association between levels of Treg cells and T-cell activation in HIV-infected patients with and without TB.

\section{Research method and design Study population and diagnostic tools}

Recruitment of study participants and collection of clinical information took place at the department of Pneumophthisiology at the National Hospital Center of Fann. In total, 69 adult patients ( $\geq 18$ years old) seen by one physician between January 2010 and June 2011 were enrolled in this study. Only MTB-infected patients who had not received TB treatment two weeks prior to blood collection were included. HIV-infected patients did not receive any antiretroviral treatment. Pregnant women were excluded from the study.

HIV was diagnosed by means of an enzyme-linked immunosorbent assay (ELISA) serological test (Genscreen HIV Ag/Ab, Bio-rad, Marnes La Coquette, France) and all positive HIV serology tests were confirmed by Western blot (HIV BLOT 2.2, Diagnostic Biotechnology Ltd., USA). TB was diagnosed by microscopic examination and/or sputum culture on solid medium Lowenstein-Jensen slopes (active pulmonary TB) or by biopsy, microscopic examination and/ or culture fluid effusion (active extrapulmonary TB). Study participants were distributed into four groups based on HIV and TB status.

\section{$\mathrm{CD}^{+}$and $\mathrm{CD} 8^{+} \mathrm{T}$-cell counts}

Laboratory testing was conducted at the Immunology Unit in the Laboratory of Virology and Bacteriology at Aristide Le Dantec University Hospital. For investigation of immunological status, $\mathrm{CD}^{+}$and $\mathrm{CD}^{+} \mathrm{T}$-lymphocytes were counted by flow cytometry using a FACSCount instrument (Becton Dickinson, San Jose, CA, USA). In short, $50 \mu \mathrm{l}$ of blood collected in a $\mathrm{K}_{3}$ EDTA-vacutainer tube was added to each of the tubes, containing the CD4 or CD8 reagents. After incubation for one hour at room temperature in the dark, $50 \mu \mathrm{l}$ of paraformaldehyde was added to each of the tubes, which were then analysed as laid out below.

\section{Analysis of regulatory and activation markers by flow cytometry}

To assess regulatory and activation status of the T- lymphocyte population, cell-surface staining was performed using three different panels of fluorochromeconjugated monoclonal antibodies - panel 1: FITC-conjugated anti-CD3, PerCP-conjugated anti-CD8 and PE-conjugated anti-CD38; panel 2: FITC-conjugated anti-CD3, PerCPconjugated anti-CD8 and PE-conjugated anti-HLA-DR; and panel 3: PerCP-conjugated anti-CD4, APC-conjugated antiCD25 and PE-conjugated anti-CD127. All antibodies and reagents were obtained from BD Biosciences (San Jose, CA, USA). Fifty $\mu \mathrm{l}$ of whole blood was added to a $5 \mathrm{ml}$ FACS tube for panels 1 and 2, whereas $100 \mu$ l of whole blood was used for panel 3. The 3 tubes were then vortexed and incubated for 15 minutes at room temperature in the dark. Subsequently, 900 $\mu \mathrm{l}$ of lysing solution was added into tubes 1 and 2, and $1800 \mu \mathrm{l}$ into tube 3. Preparations were vortexed again and incubated for an additional 15 minutes at room temperature in the dark. Finally, supernatants were removed by centrifugation at 1800 rpm, washed once with $1 \mathrm{ml}$ of PBS/1\%BSA $/ 0.05 \% \mathrm{NaN}_{3}$ and once again with $1 \mathrm{ml}$ of PBS/1\%BSA. The pellets were resuspended in $400 \mu \mathrm{l}$ of fixation solution (PBS/1\% BSA/PFA) and the percentages of CD38 and HLA-DR expressing T-cells and Tregs were counted and analysed on a FACSCalibur ${ }^{\mathrm{TM}}$ flow cytometer (Becton Dickinson, San Jose, CA, USA). Dot plots were analysed using CellQuest ${ }^{\mathrm{TM}}$ Pro 5.1 software.

\section{Statistical analysis}

Data were collected in Excel and analysed with SPSS 17 (SPSS Inc, Chicago, IL, USA). Graphs were created in Prism 5 (GraphPad, La Jolla, CA, USA). Differences between groups were assessed for statistical difference using nonparametric Kruskal-Wallis $\mathrm{H}$ and Mann-Whitney U tests and Student's $t$-tests. We used the pairwise test to assess the similarity levels of matched $\mathrm{CD} 4^{+}$counts. Correlations were calculated using the nonparametric Spearman test. The level of significance for all statistical tests was set at $p<0.05$.

\section{Results}

\section{Study subjects}

The study analysed blood samples from 69 participants distributed throughout 4 groups: TB-HIV- (controls) $(n=10), \mathrm{TB}+\mathrm{HIV}+(n=20), \mathrm{TB}+\mathrm{HIV}-(n=19)$ and TB-HIV+ $(n=20)$. The median age in years [minimum-maximum] for each group was: TB-HIV- (35 [18-45]), TB+HIV+ (43 [30-65]), TB+HIV- (32 [19-65]) and TB-HIV+ (28 [18-65]).

\section{$\mathrm{CD}^{+}$and $\mathrm{CD} 8^{+} \mathrm{T}$-cell counts}

Immunological status was assessed using $\mathrm{CD}^{+}{ }^{+} \mathrm{T}$-cell counts. We found a classic decrease of $\mathrm{CD} 4^{+} \mathrm{T}$-cells in HIVinfected subjects compared with HIV-free individuals. We also found a stronger degree of immunodeficiency in the $\mathrm{TB}+\mathrm{HIV}+$ group (median 89 cells $/ \mathrm{mm}^{3}$ [interquartile range (IQR): 27-217]) compared with the TB-HIV+ group (median 311 cells $/ \mathrm{mm}^{3}$ [IQR: 96-504]) $(p=0.04)$ (Figure 1). 
Moreover, $75 \%$ of the $\mathrm{TB}+\mathrm{HIV}+$ patients had $\mathrm{CD}^{+}$cell counts under 200 cells $/ \mathrm{mm}^{3}$, whilst only $40 \%$ of the HIV single-infected group had reached this level. However, CD8 ${ }^{+}$ $\mathrm{T}$-cell counts were not statistically different between TB+ and TB- HIV patients $(p=0.08)$ (Figure 1$)$.

In order to avoid a bias by comparing $\mathrm{T}$-cell activation markers and Treg cells between TB+ and TB- HIV infected patients with different $\mathrm{CD}^{+}$counts, patients were matched two by two for absolute CD4 ${ }^{+}$counts, and 12 CD4-matched patients were found within the groups TB-HIV+ $(189.0$ cells / $\left.\mathrm{mm}^{3}\right)$ and TB+HIV+ $\left(190.3\right.$ cells $\left./ \mathrm{mm}^{3}\right)$.

\section{CD38 and HLA-DR expression on T-cells}

To assess T-cell activation in the different groups, we calculated the percentages of $\mathrm{CD}^{+} \mathrm{T}$-cells and $\mathrm{CD} 4^{+} \mathrm{T}$-cells expressing CD38 and HLA-DR. The gating strategy is shown in Figure 2. The percentage of $\mathrm{CD}^{+} \mathrm{T}$-cells expressing CD38 was significantly higher in the $\mathrm{TB}+\mathrm{HIV}+$ group (median $68.5 \%$ [IQR: 59.6-88.5]) compared with the TB-HIV- (median 46.8\% [IQR: 43.5-55.0]) $(p<0.001)$ and TB+HIV- (median 62.2\% [IQR: 45.7-69.3]) groups ( $p=0.03$ ) (Figure 3A). However, the difference between the TB+HIV+ and TB-HIV+ groups did not reach statistical significance $(p=0.14)$.

The percentage of $\mathrm{CD}^{+}$T-cells expressing CD38 was significantly higher in the $\mathrm{TB}+\mathrm{HIV}+$ group (median $88.6 \%$ [IQR: 79.9-94.4]) compared with the TB-HIV+ group (median 65.5\% [IQR: 47.4-88.3]) $(p=0.01)$ and also compared with both HIV-seronegative groups (TB+HIV- $[p<0.001]$ and TB-HIV- $[p<0.001]$ ) (Figure 3B).

With regard to HLA-DR expression in T-cells, we found that the $\mathrm{TB}+\mathrm{HIV}+$ group displayed a significantly higher percentage of $\mathrm{CD}^{+}$cells expressing HLA-DR (median $41.2 \%$ [IQR: 19.0-59.2]) as compared with the TB-HIV- $(p<0.001)$ and $\mathrm{TB}+\mathrm{HIV}-$ groups $(p<0.001)$ (Figure $3 \mathrm{C})$. However, the difference between the TB+HIV + and TB-HIV+ groups did not reach statistical significance $(p=0.12)$. Finally, the percentage of $\mathrm{CD}^{+}$T-cells expressing HLA-DR was significantly higher in the TB+HIV+ group (median $66.2 \%$ [IQR: 61.2-79.9]) than in the TB-HIV+ group (median 45.8\% [IQR: 32.6-64.9]) $(p=0.006)$ as well as both HIV-seronegative groups (Figure 3D).

To correct for the bias due to differences in absolute CD4 counts between the two HIV+ groups (TB+ and TB-), patients were matched for absolute $\mathrm{CD} 4^{+}$counts in the TB-HIV+ and $\mathrm{TB}+\mathrm{HIV}+$ groups. $\mathrm{CD} 4$ values from the TB-HIV+ group have been linked to the approximately similar $\mathrm{CD} 4$ values from the $\mathrm{TB}+\mathrm{HIV}+$ group, with the following maximum differences in CD4 counts between the two matched subjects for each of four pre-established ranges: maximum difference of 20 cells for CD4 counts $<100$ cells $/ \mathrm{mm}^{3}$, maximum difference of 40 cells between 100 and 200 cells $/ \mathrm{mm}^{3}$, maximum difference of 60 cells between 200 and 500 cells $/ \mathrm{mm}^{3}$ and maximum difference of 120 cells for CD4 counts $>500$ cells $/ \mathrm{mm}^{3}$. Following these criteria, we found 12 CD4-matched patients in the TB-HIV+ (mean: 189.0 cells $/ \mathrm{mm}^{3}$ ) and $\mathrm{TB}+\mathrm{HIV}+$ (mean: 190.3 cells $/ \mathrm{mm}^{3}$ ) groups (paired difference of the means $=1.08 ; p=0.989)$. CD38 and HLA-DR expression on $\mathrm{CD}^{+}$and $\mathrm{CD}^{+}$T-cells were significantly higher in the $\mathrm{TB}+\mathrm{HIV}+$ as compared with $\mathrm{TB}-\mathrm{HIV}+$ groups (Figure 4).

\section{Impact of tuberculosis on expression of Tregs in HIV-infected patients}

The TB-HIV+ group showed a significantly higher percentage of Treg cells compared with both HIV-seronegative groups $(p<0.001)$ (Figure 5A), as did the TB+HIV+ group $(p<0.001)$. However, there was no statistically-significant difference between the TB+HIV+ and TB-HIV+ groups $(p=0.587)$.

When matching for absolute CD4 counts between the $\mathrm{TB}-\mathrm{HIV}+$ and TB+HIV+ group, no significant difference in the percentage of Tregs was found between the two groups (Figure 4).

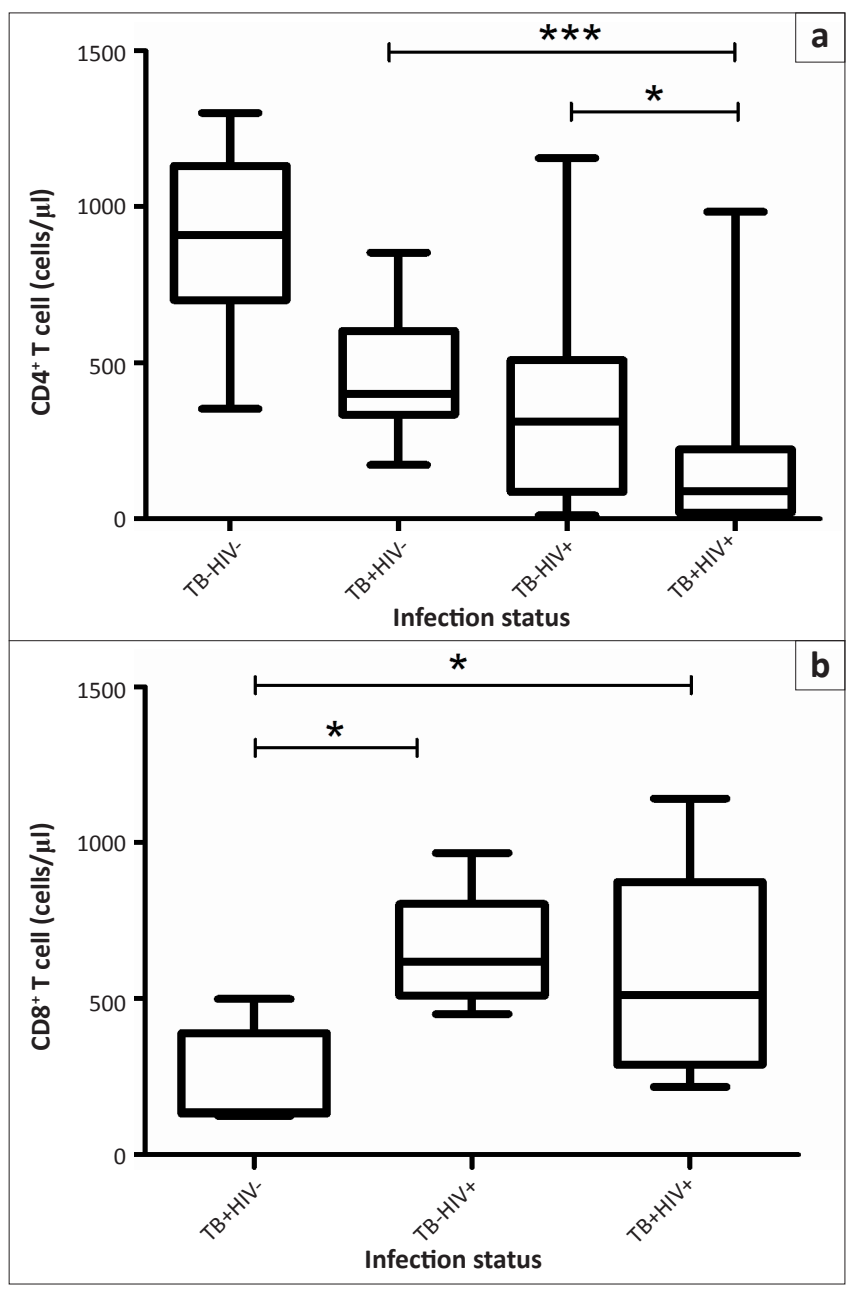

Source: Authors' own construction

*, $p<0.05 ;{ }^{* * *}, p<0.001$; TB, tuberculosis; HIV, Human Immunodeficiency Virus; -, negative; + , positive.

negative; + , positive.
Note are expressed as median values and interquartile ranges. $p$-values were calculated in SPSS 17 using the nonparametric Mann-Whitney U test and graph was generated using GraphPad Prism. CD4 ${ }^{+}$T-cell count was significantly higher in the control group (TB-HIV-) compared with all the other groups ( $p$-values not shown). CD8 ${ }^{+} \mathrm{T}$-cell counts were not conducted on the control group (TB-HIV-).

FIGURE 1: T-cell lymphocyte counts. Representative box-and-whisker plots of counts of (a) $\mathrm{CD}^{+}$and (b) CD8 ${ }^{+}$T-cells in TB-HIV- $(n=10), \mathrm{TB}+\mathrm{HIV}-(n=19)$, $\mathrm{TB}-\mathrm{HIV}+(n=20)$, and TB+HIV+ $(n=20)$ groups are shown. 


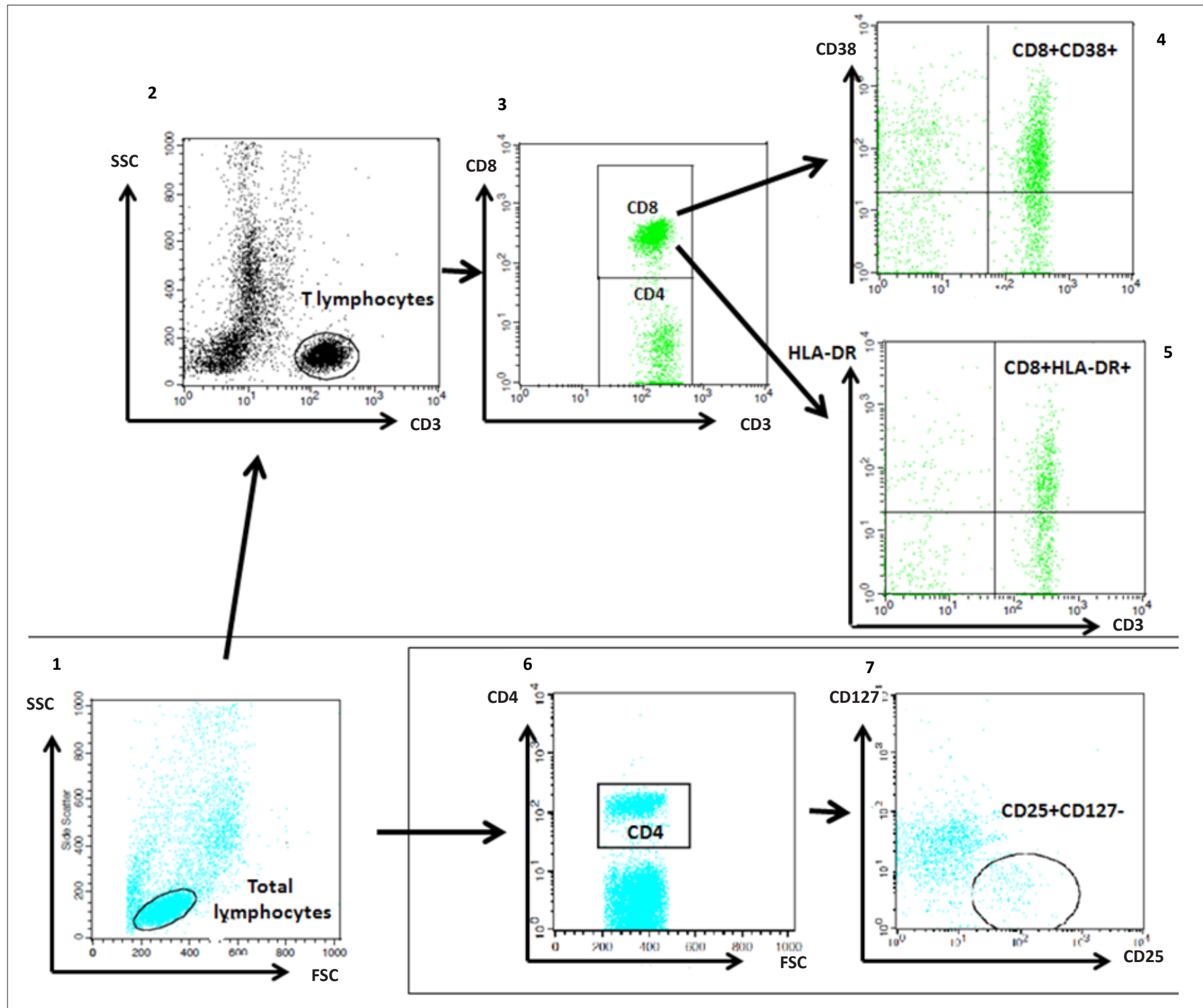

Source: Authors' own construction

Note: Flow cytometry plots of CD38+- and HLA-DR-expressing CD8+ T-cells and CD4+CD25+CD127--expressing CD4 $4^{+}$-cells analysed using CellQuest Pro. From total lymphocytes (1), we identified T-cell lym phocytes $\left(\mathrm{CD3}^{+}\right)(2)$ which were then separated into $C D 8^{+}$and $C D 4^{+} \mathrm{T}$-cells (3). From CD8 ${ }^{+} \mathrm{T}$-cells, CD38 (4) and HLA-DR (5) were identified in the upper right quadrant of the corresponding plots. CD8 and HLA-DR on CD4 ${ }^{+}$T-cells were similarly defined (cytometry plots not shown). To identify Treg cells, we isolated CD4+ T-cells (6) from total lymphocytes (A) and then analysed CD25 and CD127. In the CD25/CD127 plot, Treg cells were defined as CD25 positive and CD127 negative population (7).

FIGURE 2: Gating strategy for assessing T-cell activation markers and regulatory T-cells.

\section{Correlation between $\mathrm{CD}^{+} \mathrm{T}$-cell counts and Treg cells and activation markers}

$\mathrm{CD} 4^{+} \mathrm{T}$-cell counts were inversely correlated with fractions of Tregs in both the TB-HIV+ $(r=-0.663 ; p=0.001)$ and $\mathrm{TB}+\mathrm{HIV}+(r=-0.447 ; p=0.048)$ groups (Figure 6A).

In the HIV-infected group (TB-HIV+), Tregs were also negatively correlated with both $\mathrm{CD}^{+} \mathrm{CD} 38^{+}(r=-0.50$; $p=0.022)$ and $\mathrm{CD} 4+\mathrm{HLA}^{-\mathrm{DR}^{+}}(r=0.74 ; p<0.0001)$ (Figure not shown).

\section{Ethical considerations}

The study protocol has been approved by Le Comité National d'Ethique de la Recherche en Santé of Senegal (Permit Number: 000015MSAS/DPRS/CNERS) and the review board of the Institute of Tropical Medicine of Antwerp (Permit Number: $\mathrm{IRB} / \mathrm{AB} / \mathrm{ac} / 066)$.

\section{Potential benefits and hazards}

There was no direct risk related to this study since the samples used were taken for routine biological monitoring (for HIV- and TB-infected patients) and for voluntary HIV testing (for controls) that are collected independent of any research activity.

The participants were followed up regularly at the Department of Pneumo-phthisiology of Fann University Hospital where the Ministry of Health and the National AIDS Programme support all medical and social aspects including care and protection. Healthy controls consisted of volunteers enrolled from the same department where the National AIDS Programme also supports the voluntary HIV testing.

\section{Recruitment procedures}

Participation was totally voluntary and written informed consent was obtained from each subject. 


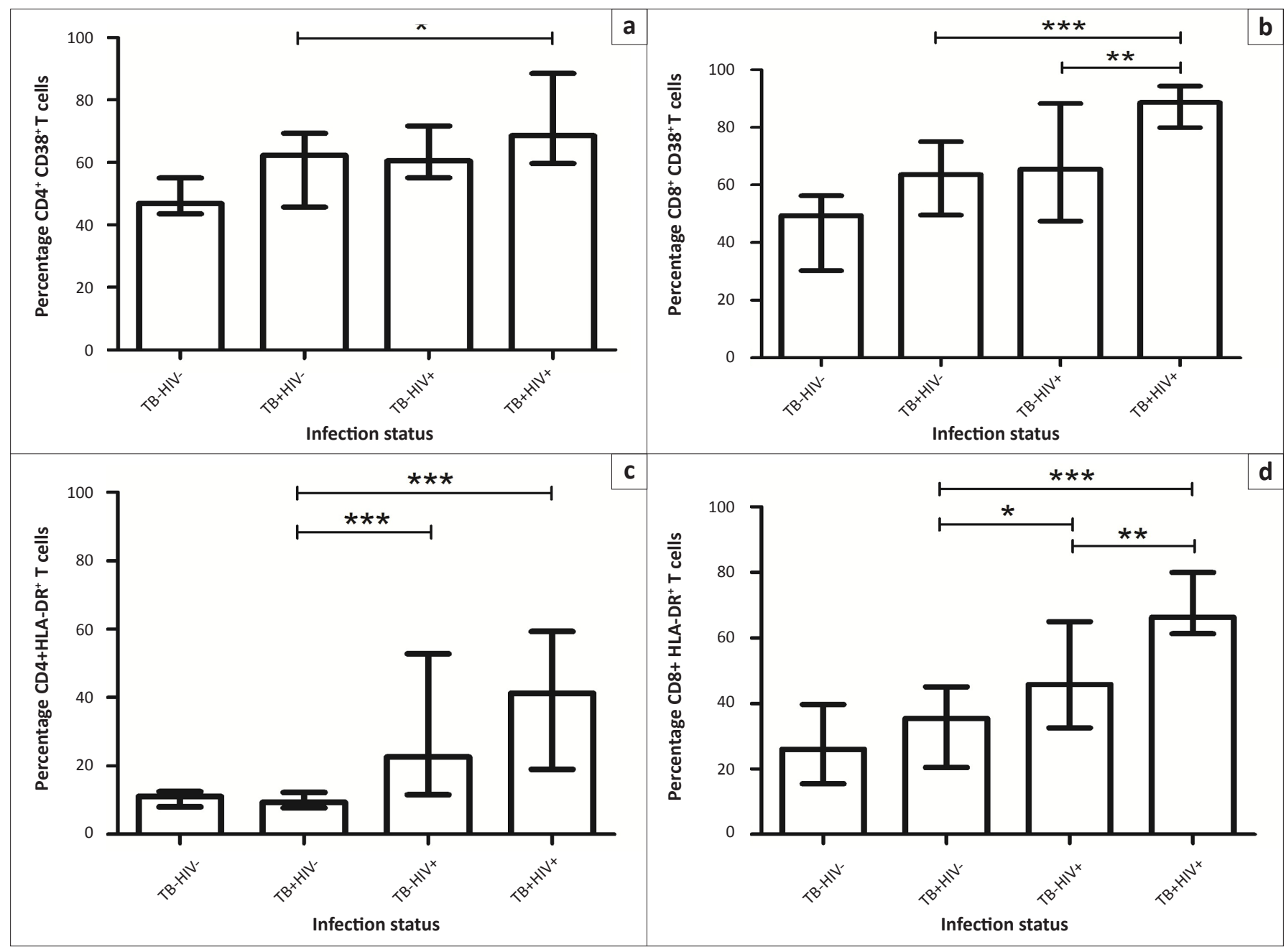

Source: Authors' own construction

${ }^{*}, p<0.05 ;{ }^{* *}, p<0.01 ;{ }^{* * *}, p<0.001 ; \mathrm{TB}$, tuberculosis; HIV, Human Immunodeficiency Virus; - , negative; + , positive.

Note: Data are expressed as median values and interquartile ranges. $p$-values were calculated in SPSS 17 using the nonparametric Mann-Whitney $\mathrm{U}$ test and graphs were generated using GraphPad Prism. The parameters presented in Figures A, B, and D were significantly lower in the group of control (TB-HIV-) compared with all the other groups ( $p$-values not shown): in Figure C, CD4 ${ }^{+} \mathrm{HLA}_{-} \mathrm{DR}^{+}$frequency was lower in the group of controls (TB-HIV-) compared with TB-HIV+ and TB+HIV+ groups, but showed no significant difference compared with TB+HIV(p-values not shown).

FIGURE 3: T-cell activation markers. Representative column bars show percentages of (A) $\mathrm{CD} 4^{+} \mathrm{CD} 38^{+}$, (B) $\mathrm{CD} 8^{+} \mathrm{CD} 38^{+},(\mathrm{C}) \mathrm{CD} 4^{+} \mathrm{HLA}-\mathrm{DR} \mathrm{R}^{+}$and (D) $\mathrm{CD} 8^{+} \mathrm{HLA}-\mathrm{DR} \mathrm{R}^{+} \mathrm{T}-\mathrm{ce}$ lls in the TB-HIV- $(n=10), \mathrm{TB}+\mathrm{HIV}-(n=19), \mathrm{TB}-\mathrm{HIV}+(n=20)$ and TB+HIV+ $(n=20)$ groups.

\section{Informed consent}

Through an informed consent presentation by a social worker, participants were informed about the study and how it would be conducted, including the benefits and risks, voluntary participation and confidentiality.

\section{Data protection}

Results as well as clinical and social information are strictly confidential. Participants' names or any other information that may allow identification of the subjects were not - and will not be - used in written or oral reports or in scientific publications.

It was also specified in the consent form that samples will be kept for at least 10 years after the study for eventual future investigations and that any participant had the right to refuse storage of the sample and ask the biological material be destroyed.

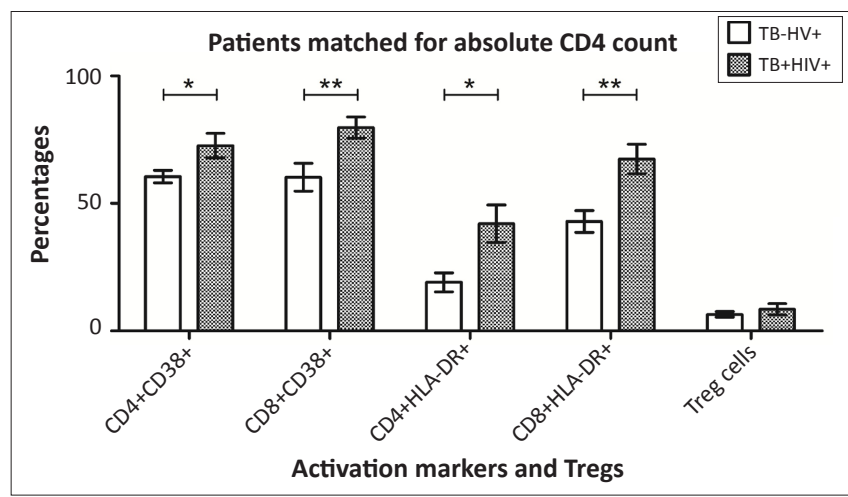

Source: Authors' own construction

*, $p<0.05$; **, $p<0.01$; TB, tuberculosis; HIV, Human Immunodeficiency Virus; -, negative + , positive.

Note: Percentages are expressed as mean values and standard deviation. $p$-values were calculated in SPSS 17 using Student's $t$-test. Only statistically-significant $p$-values are shown in the figures.

FIGURE 4: Activation markers and Treg cells matched for absolute CD4 counts. Representative column bars of percentage of T-cell activation markers and Treg cells in the TB-HIV+ $(n=12)$ and $\mathrm{TB}+\mathrm{HIV}+(n=12)$ group that were matched for absolute $\mathrm{CD}^{+} \mathrm{T}$-cell counts (mean $\mathrm{CD}^{+}$was 189.0 cells $/ \mathrm{mm}^{3}$ and 190.3 cells/ $\mathrm{mm}^{3}$ for TB-HIV+ and TB+HIV+ respectively). 


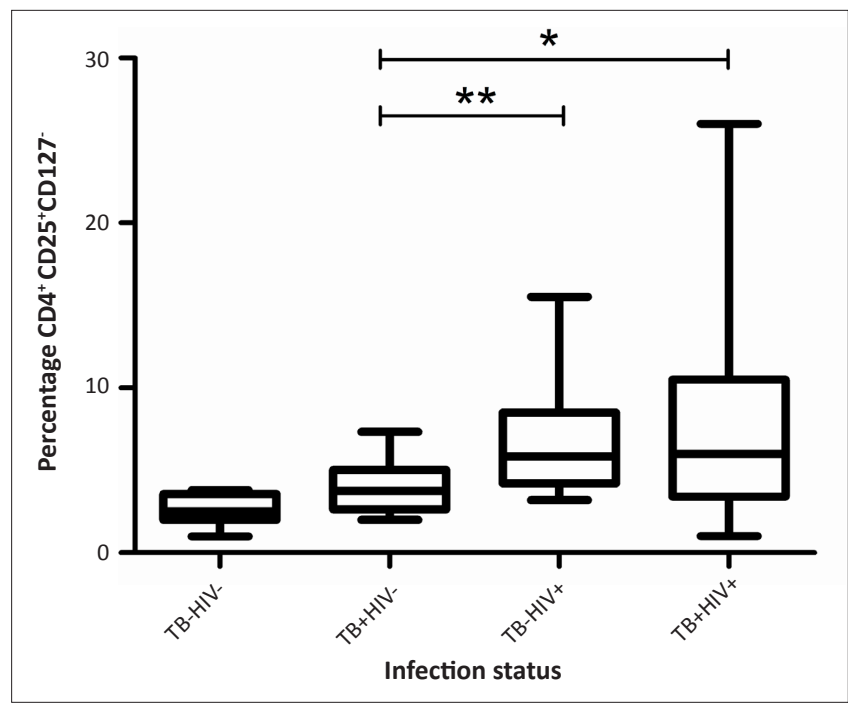

Source: Authors' own construction

*, $p<0.05 ; * *, p<0.01$; TB, tuberculosis; HIV, Human Immunodeficiency Virus; negative; + , positive

Note: Data are expressed as median values and interquartile ranges.. $p$-values were calculated in SPSS 17 using the nonparametric Mann-Whitney $U$ test and graph was performed using GraphPad Prism. Treg cell-count was significantly lower in the group of controls (TB-HIV-) compared with all the other groups ( $p$-values not shown).

FIGURE 5: Regulatory T-cells. Representative box-and-whisker plot of percentage of CD4+CD $25^{+} \mathrm{CD} 127^{-}$in the TB-HIV- $(n=10), \mathrm{TB}+\mathrm{HIV}-(n=19)$, $\mathrm{TB}-\mathrm{HIV}+(n=20)$ and $\mathrm{TB}+\mathrm{HIV}+(n=20)$ groups.

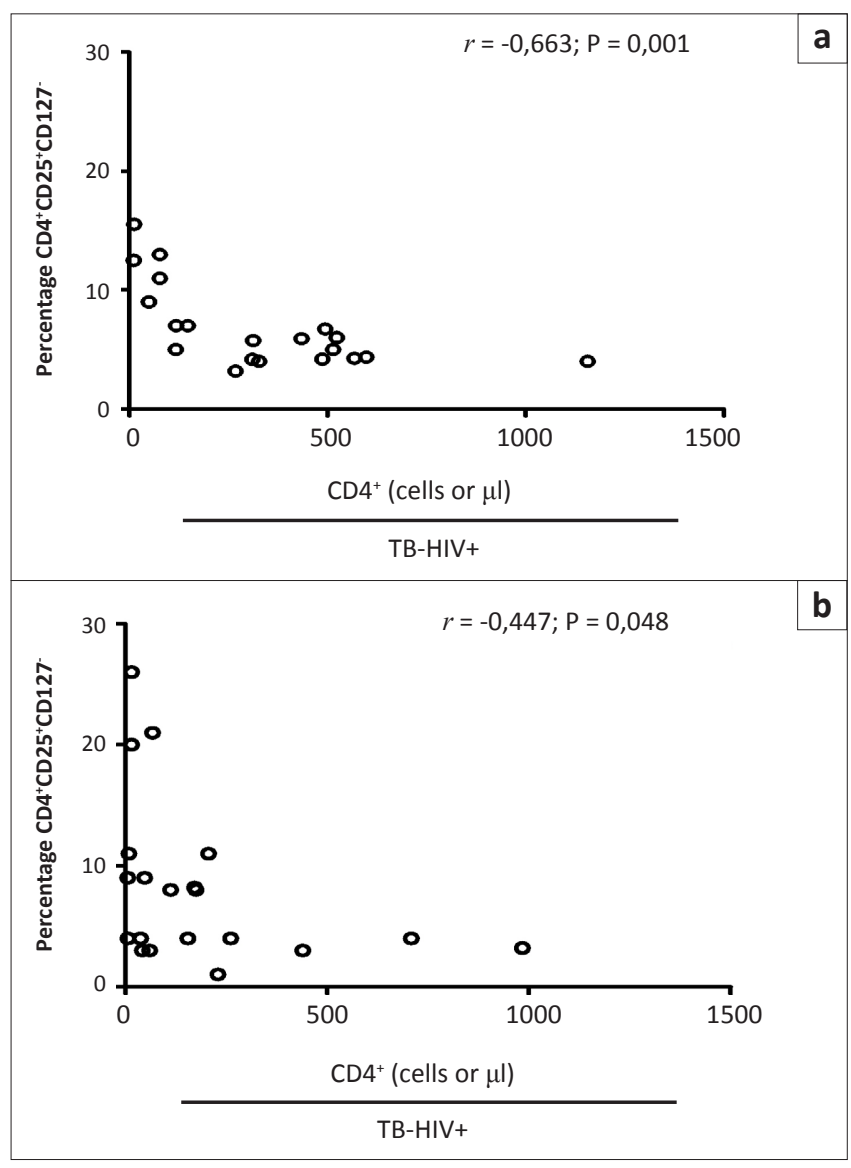

Source: Authors' own construction

Note: Correlations were calculated in SPSS 17 using the Spearman test and graphs were performed using GraphPad Prism.

FIGURE 6: Correlation between CD4+ T-cell counts and frequencies of Treg cells. Negative correlation between $\mathrm{CD} 4^{+} \mathrm{CD} 25^{+} \mathrm{CD} 127^{-} \mathrm{T}$-cells and $\mathrm{CD} 4+\mathrm{T}$-cell count (A) in TB-HIV+ group $(r=-0.663, p=0.001)$ and $(B)$ in TB+HIV+ group $(r=-0.447$, $p=0.048$ ).

\section{Trustworthiness}

This study was conducted at the laboratory of Bacteriology and Virology of Aristide Le Dantec University Hospital which is a UN/AIDS Reference Centre for the biological monitoring of HIV patients. All the units comprising the laboratory (virology, bacteriology, immunology, and molecular biology have subscribed to external quality control programmes to ensure their quality approach and the trustworthiness of their results.

\section{Reliability}

A default FACSCalibur template was drawn up using optimal compensation for accurate detection of the parameters of interest. For any new sample, T-cell markers were assessed using this template without changing any of the parameters.

Calibration and laser alignment of the FACSCalibur ${ }^{\mathrm{TM}}$ instrument used were performed periodically in order to ensure reliability of the system.

\section{Validity}

Staining controls were used when assessing T-cell markers by flow cytometry. For parameters that do not show clear separation between positive and negative populations, the positive population was set based on FMO (Fluorescence Minus One) control panels that lacked one of the researchers' desired fluorochrome-associated markers in order to assess the negative limit.

\section{Discussion}

HIV single-infected and HIV and/or TB co-infected patients displayed increased T-cell activation compared with HIVuninfected subjects. These results are consistent with findings that HIV infection and HIV and/or TB co-infection are associated with peripheral activation of the immune system. $.833,34,35,36,37$

Immune activation caused by HIV mediates increased proliferation of $\mathrm{CD}^{+}$cells and makes these cells more vulnerable to infection and destruction by HIV, accelerating the progressive exhaustion of $\mathrm{CD}^{+}$cells. ${ }^{38,39}$ Our results showed that the expression of both CD38 and HLA-DR on $\mathrm{CD}^{+} \mathrm{T}$-cells, but not on $\mathrm{CD} 4^{+} \mathrm{T}$-cells, was significantly higher in TB+HIV+ patients than in the TB-HIV+ patients. After matching for absolute CD4 counts, CD38 and HLA-DR expression were significantly higher on both $\mathrm{CD} 4^{+}$and $\mathrm{CD} 8^{+}$ $\mathrm{T}$-cells in TB+HIV+ patients as compared with those who were TB-HIV+. This indicates that HIV and/or TB co-infection is associated with additional T-cell activation as compared with HIV infection alone, which may favour HIV progression.

Patients with TB alone also displayed higher expression of peripheral $\mathrm{CD} 38$ on $\mathrm{CD}^{+}$and $\mathrm{CD}^{+}$T-cells than the uninfected controls, although the differences were not statistically significant. These results are, however, in line with previous findings, suggesting that infection with TB is associated with immune activation. ${ }^{40}$ 
For the purposes of this study, Tregs were defined as being $\mathrm{CD} 4^{+} \mathrm{CD} 25^{+} \mathrm{CD} 127^{-} \mathrm{T}$-cells. There is still controversy about $\mathrm{CD} 4{ }^{+} \mathrm{CD} 25^{+} \mathrm{CD} 127^{\text {low } /-}$ and $\mathrm{CD} 4{ }^{+} \mathrm{CD} 25^{+} \mathrm{FoxP} 3^{+}$identifying the same subset of Treg cells; however, a recent study published in Cytometry has confirmed that both subsets can be used to identify Tregs. ${ }^{32}$ Our results show that HIV-infected patients had a significantly higher percentage of Tregs than the controls. This is consistent with previous studies that have shown an increase of Treg cells in HIV-infected patients. ${ }^{41,42}$ Moreover, the inverse correlation between the percentage of Tregs and the absolute $\mathrm{CD}^{+}{ }^{+} \mathrm{T}$-cell counts amongst HIV-infected patients suggests that relative increase of $\mathrm{CD} 4^{+} \mathrm{CD} 25^{+} \mathrm{CD} 127^{-} \mathrm{T}$-cells is a marker of disease severity, as reported recently in a study using the $\mathrm{CD} 4^{+} \mathrm{CD} 25^{+} \mathrm{Foxp} 3^{+}$ Treg subset. ${ }^{20}$

An important question to address is whether active TB has an impact on the expression of Tregs; this may help to understand, at least partly, the mechanisms by which TB alters the clinical course of HIV. It has been proposed that Treg cells may be upregulated during HIV infection to avoid overactive immunity and therefore protect against viral replication ${ }^{17}$ and tissue damage, ${ }^{43}$ and that $T B$, which is implicated in faster progression of HIV infection, may be associated with lower levels of Treg cells. On the other hand, another group has reported that higher levels of Treg cells may lead to reduced immune responses and favour the pathogen over the host, and that immunodeficiency is expected to be aggravated if Treg cells are present in a greater amount. ${ }^{23,24}$ This study did not find any significant difference in the expression of Treg cells between HIV single-infected patients and TB and/or HIV co-infected subjects - neither in the whole study group nor in groups matched for absolute CD4 counts - suggesting that TB has no additional effect on the expression of Tregs in HIV-infected patients. Thus, our results seem to indicate that the mechanisms by which TB acts on HIV progression do not affect the number of Tregs. However, a limitation of this study is that Treg functionality was not assessed. Because Treg cells are a subset of CD4 ${ }^{+}$ T-cells, a fraction of studied Tregs may have been lost or became nonfunctional following immunosuppression or immune activation associated with HIV infection.

Investigation of $\mathrm{CD}^{+}$and $\mathrm{CD}^{+} \mathrm{T}$-cell counts revealed significantly fewer CD4 ${ }^{+}$T-cells in TB and HIV co-infected patients compared with single-infected subjects with either $\mathrm{TB}$ or HIV alone, suggesting a more advanced immunodeficiency in co-infected patients. Similar results have been reported by Ddo et al. who found that TB contributes to the decrease in $\mathrm{CD}^{+}{ }^{+} \mathrm{T}$-cell count during TB and/or HIV co-infection. ${ }^{37}$ Several studies have reported an association of TB with the acceleration of immunodeficiency and increased virus replication in HIV infection. . $, 6,40,44,45,46$ With this in mind, our finding that $75 \%$ of co-infected patients had reached the stage of clinical AIDS $\left(\mathrm{CD} 4<200 / \mathrm{mm}^{3}\right)$, compared with $40 \%$ of the HIV single-infected patients, is not surprising.

In summary, we found that expression of CD38 and HLA$\mathrm{DR}$ on $\mathrm{CD}^{+}$and $\mathrm{CD} 8{ }^{+} \mathrm{T}$-cells was higher in TB and/or HIV co-infected patients as compared with HIV single-infected individuals. However, TB and/or HIV co-infected patients did not express Treg cells differently from HIV singleinfected patients. These results suggest that TB accelerates HIV disease progression mainly through its impact on $\mathrm{CD}^{+}$and $\mathrm{CD}^{+}{ }^{+} \mathrm{T}$-cell activation, but not by changing the percentages of Tregs. In order to better clarify the role of T-cell activation markers and Treg cells in HIV disease progression amongst TB and/or HIV co-infected patients, additional investigations considering the compartments studied, the stage of the disease, the HIV viral loads and the functionality of Treg cells are warranted.

\section{Limitations of the study}

This study was subject to some limitations, one being that the study groups used were relatively small; a larger sample size may be required to discern statistically significant differences in certain categories between certain groups. HIV viral loads were not measured at all and $\mathrm{CD} 8^{+} \mathrm{T}$-cell counts were not looked at amongst the controls. As mentioned previously, Treg functionality was not assessed.

\section{Acknowledgements}

We are grateful to and would like to thank all the participants of this study for their collaboration. This study would not have been possible without the medical staff of the department of pneumo-phthisiology of Fann Hospital and the staff of the Immunology Unit of the Laboratory of Bacteriology and Virology, who are also deserving of our thanks. This study was co-funded by the Direction Générale pour le Développement (DGD) de Belgique.

\section{Competing interests}

The authors declare that they have no financial or personal relationship(s) which may have inappropriately influenced them in writing this article.

\section{Authors' contributions}

T.N.D. (University of Dakar), S.M. (University of Dakar), L.K. (Institute of Tropical Medicine of Antwerp, and University of Antwerp), G.D. (Institute of Tropical Medicine of Antwerp) and A.N. (Clinic of Infectious Disease, Fann Hospital) conceived and designed the study. M.C. (University of Dakar), A.A.D. (Laboratory of Bacteriology and Virology, Aristide Le Dantec University Hospital) and P.A.D. (Laboratory of Bacteriology and Virology, Aristide Le Dantec University Hospital) designed the experiments. N.S.S.S. and D.W. (Laboratory of Bacteriology and Virology, Aristide Le Dantec University Hospital) performed the experiments. M.M. (Laboratory of Bacteriology and Virology, Aristide Le Dantec University Hospital), N.S.S.S. and M.C. analysed and interpreted the data. S.M., L.K. and T.N.D. contributed to reagents/materials/analysis tools. M.M. and N.S.S.S. wrote/ drafted the manuscript. A.B., M.T., M.D. and N.L. (Laboratory of Bacteriology and Virology, Aristide Le Dantec University Hospital), D.W., G.D., L.K., M.C., T.N.D and S.M. reviewed the manuscript critically for important intellectual content. L.K., G.D., T.N.D. and S.M. approved the final version for publication. 


\section{References}

1. Mayer KH, Dukes HC. Synergistic pandemics: confronting the global HIV and tuberculosis epidemics. Clin Infect Dis. 2010;50 Suppl 3:S67-S70. http://dx.doi. org/10.1086/651475, PMid:20397958

2. Markowitz N, Hansen NI, Hopewell PC, et al. Incidence of tuberculosis in the United States among HIV-infected persons. The Pulmonary Complications of HIV Infection Study Group. Ann Intern Med. 1997;126(2):123-132. http://dx.doi. org/10.7326/0003-4819-126-2-199701150-00005, PMid:9005746

3. Grossman Z, Meier-Schellersheim M, Sousa AE, et al. CD4+ T-cell depletion in HIV infection: are we closer to understanding the cause? Nat Med. 2002;8(4):319323. http://dx.doi.org/10.1038/nm0402-319, PMid:11927927

4. Goletti D, Weissman D, Jackson RW, et al. Effect of Mycobacterium tuberculosis on HIV replication. Role of immune activation. J Immunol. 1996;157(3):1271-1278. PMid: 8757635

5. Goletti D, Weissman D, Jackson RW, et al. The in vitro induction of human immunodeficiency virus (HIV) replication in purified protein derivative-positive HIV-infected persons by recall antigen response to Mycobacterium tuberculosis is the result of a balance of the effects of endogenous interleukin-2 and proinflammatory and antiinflammatory cytokines. J Infect Dis. 1998;177(5):13321338.http://dx.doi.org/10.1086/515276, PMid:9593021

6. Whalen C, Horsburgh CR, Hom D, et al. Accelerated course of human immunodeficiency virus infection after tuberculosis. Am J Respir Crit Car Med. 1995;151(1):129-135. http://dx.doi.org/10.1164/ajrccm.151.1.7812542, PMid:7812542

7. Zhang $\mathrm{Y}$, Nakata $\mathrm{K}$, Weiden $\mathrm{M}$, et al. Mycobacterium tuberculosis enhances human immunodeficiency virus-1 replication by transcriptional activation at the long terminal repeat. J Clin Invest. 1995;95(5):2324-
JCI117924, PMid:7738195, PMCid:PMC295846

8. Vanham G, Edmonds K, Qing L, et al. Generalized immune activation in pulmonary tuberculosis: co-activation with HIV infection. Clin Exp Immunol. 1996;103(1):3034. http://dx.doi.org/10.1046/j.1365-2249.1996.907600.x, PMid:8565282, PMCid:PMC2200321

9. Xiao J, Qian KL, Cao QH, et al. HLA-DR expression on regulatory T cells is closely associated with the global immune activation in HIV-1 infected subjects naive to antiretroviral therapy. Chin Med J (Engl). 2011;124(15):2340-2346.

10. Sousa AE, Carneiro J, Meier-Schellersheim M, et al. CD4 T cell depletion is linked directly to immune activation in the pathogenesis of HIV-1 and HIV-2 but only indirectly to the viral load. J Immunol. 2002;169(6):3400-3406. PMid:12218162

11. Bentwich Z, Kalinkovich A, Weisman Z. Immune activation is a dominant factor in the pathogenesis of African AIDS. Immunol Today. 1995;16(4):187-191. http:// the pathogenesis of African AIDS. Immunol

12. Appay V, Sauce D. Immune activation and inflammation in HIV-1 infection: causes and consequences. J Pathol. 2008;214(2):231-241. http://dx.doi.org/10.1002/ path.2276, PMid:18161758

13. Kestens $L$, Vanham $G$, Vereecken $C$, et al. Selective increase of activation antigen HLA-DR and CD38 on CD4+ CD45RO+ T lymphocytes during HIV-1 infection. Clin Exp Immunol. 1994;95(3):436-441. http://dx.doi.org/10.1111/j.1365-2249.1994. tb07015.x, PMid:7907956, PMCid:PMC1535073

14. Liu Z, Cumberland WG, Hultin LE, et al. Elevated CD38 antigen expression on CD8+ T cells is a stronger marker for the risk of chronic HIV disease progression to AIDS
and death in the Multicenter AIDS Cohort Study than CD4+ cell count, soluble and death in the Multicenter AIDS Cohort Study than CD4+ cell count, soluble
immune activation markers, or combinations of HLA-DR and CD38 expression. J Acquir Immune Defic Syndr Hum Retrovirol. 1997;16(2):83-92. http://dx.doi. org/10.1097/00042560-199710010-00003, PMid:9358102

15. Papagno L, Spina CA, Marchant A, et al. Immune activation and CD8+ T-cell differentiation towards senescence in HIV-1 infection. PLoS Biol. 2004;2(2):e20. http:// differentiation towards senescence in HIV-1 infection. PLoS Biol. 2004;2(2):e20. http:/
dx.doi.org/10.1371/journal.pbio.0020020, PMid:14966528, PMCid:PMC340937

16. Levacher $M$, Hulstaert $F$, Tallet $S$, et al. The significance of activation markers on CD8 lymphocytes in human immunodeficiency syndrome: Staging and prognostic value. Clin Exp Immunol. 1992;90(3):376-382. http://dx.do . org/10.1111/j.1365-2249.1992.tb05854.x, PMid:1458674, PMCid:PMC1554578

17. Rouse BT, Sarangi PP, Suvas S. Regulatory T cells in virus infections. Immuno Rev. 2006;212:272-286. http://dx.doi.org/10.1111/j.0105-2896.2006.00412.x PMid:16903920

18. Kinter AL, Hennessey M, Bell A, et al. CD25(+)CD4(+) regulatory $T$ cells from the peripheral blood of asymptomatic HIV-infected individuals regulate $\mathrm{CD} 4(+)$ and CD8(+) HIV-specific T cell immune responses in vitro and are associated with favorable clinical markers of disease status. J Exp Med. 2004;200(3):331-343. http://dx.doi.org/10.1084/jem.20032069, PMid:15280419, PMCid:PMC2211981

19. Aandahl EM, Michaëlsson J, Moretto WJ, et al. Human CD4+ CD25+ regulatory T cells control T-cell responses to human immunodeficiency virus and
cytomegalovirus antigens. J Virol. 2004;78(5):2454-2459. http://dx.doi. cytomegalovirus antigens. J Virol. 2004;78(5):2454-2459. http://dx.
org/10.1128/JVI.78.5.2454-2459.2004, PMid:14963140, PMCid:PMC369239

20. Suchard MS, Mayne E, Green VA, et al. FOXP3 expression is upregulated in $\mathrm{CD}^{+} \mathrm{T}$ cells in progressive HIV-1 infection and is a marker of disease severity. PLoS One. 2010;5(7):e11762. http://dx.doi.org/10.1371/journal.pone.0011762, PMid:20668701, PMCid:PMC2909259

21. Xing S, Fu J, Zhang Z, et al. Increased turnover of FoxP3high regulatory $T$ cells is associated with hyperactivation and disease progression of chronic HIV-1 infection. J Acquir Immune Defic Syndr. 2010;54(5):455-462. http://dx.doi. org/10.1097/QAl.0b013e3181e453b9, PMid:20585263

22. Belkaid $Y$, Rouse BT. Natural regulatory T cells in infectious disease. Nat Immunol 2005;6(4):353-360.http://dx.doi.org/10.1038/ni1181, PMid:15785761

23. Guyot-Revol V, Innes JA, Hackforth $S$, et al. Regulatory $T$ cells are expanded in blood and disease sites in patients with tuberculosis. Am J Respir Crit Care
Med. 2006;173(7):803-810. http://dx.doi.org/10.1164/rccm.200508-12940C, Med. 2006;173
24. Stoop JN, van der Molen RG, Baan CC, et al. Regulatory T cells contribute to the impaired immune response in patients with chronic hepatitis B virus infection $\begin{array}{lll}\text { Hepatology. 2005;41(4):771-778. http://dx.doi.org/10.1002/hep.20649, } & \end{array}$ PMid:15791617

25. Epple HJ, Loddenkemper C, Kunkel D, et al. Mucosal but not peripheral FOXP3+ regulatory T cells are highly increased in untreated HIV infection and normalize after suppressive HAART. Blood. 2006;108(9):3072-3078. http://dx.doi. org/10.1182/blood-2006-04-016923, PMid:16728694

26. Tsunemi S, Iwasaki T, Imado T, et al. Relationship of CD4+CD25+ regulatory T cells to immune status in HIV-infected patients. AIDS. 2005;19(9):879-886. http:// dx.doi.org/10.1097/01.aids.0000171401.23243.56, PMid:15905668

27. Apoil PA, Puissant B, Roubinet F, et al. FOXP3 mRNA levels are decreased in peripheral blood CD4+ lymphocytes from HIV-positive patients. J Acquir Immune Defic Syndr. 2005;39(4):381-385. http://dx.doi.org/10.1097/01 qai.0000169662.30783.2d, PMid:16010156

28. Liu W, Putnam AL, Xu-Yu Z, et al. CD127 expression inversely correlates with FoxP3 and suppressive function of human CD4+ T reg cells. J Exp Med. 2006;203(7):1701-1711. http://dx.doi.org/10.1084/jem.20060772, PMid:16818678, PMCid:PMC2118339

29. Klein S, Kretz CC, Krammer PH, et al. CD127(low/-) and FoxP3(+) expression levels characterize different regulatory T-cell populations in human peripheral blood. $J$ Invest Dermatol. 2010;130(2):492-499. http://dx.doi.org/10.1038/jid.2009.313, PMid:19940860

30. Hartigan-O'Connor DJ, Poon C, Sinclair E, et al. Human CD4+ regulatory T cells express lower levels of the IL-7 receptor alpha chain (CD127), allowing consistent identification and sorting of live cells. J Immunol Methods. 2007;319(1-2):41-52. http://dx.doi.org/10.1016/j.jim.2006.10.008, PMid:17173927

31. Seddiki N, Santner-Nanan B, Martinson J, et al. Expression of interleukin (IL)-2 and IL-7 receptors discriminates between human regulatory and activated T cells. J Exp Med. 2006;203(7):1693-1700. http://dx.doi.org/10.1084/jem.20060468, PMid:16818676, PMCid:PMC2118333

32. Saison J, Demaret J, Venet F, et al. CD4+CD25+CD127- assessment as a surrogate phenotype for FOXP31 regulatory T cells in HIV-1 infected viremic and aviremic subjects. Cytometry B Clin Cytom. 2013;84(1):50-54. http://dx.doi.org/10.1002/ cyto.b.21047, PMid:23019018

33. Catalfamo M, Di Mascio M, Hu Z, et al. HIV infection-associated immune activation occurs by two distinct pathways that differentially affect CD4 and CD8 T cells Proc Natl Acad Sci USA. 2008;105(50):19851-19856. http://dx.doi.org/10.1073/ pnas.0810032105, PMid:19060209, PMCid:PMC2596741

34. Cohen Stuart JW, Hazebergh MD, Hamann D, et al. The dominant source of CD4+ and CD8+ T-cell activation in HIV infection is antigenic stimulation. J Acquir Immune Defic Syndr. 2000;25(3):203-211. http://dx.doi.org/10.1097/00126334200011010-00001, PMid:11115950

35. Hunt PW, Brenchley J, Sinclair E, et al. Relationship between T cell activation and CD4 + T cell count in HIV-seropositive individuals with undetectable plasma HIV RNA levels in the absence of therapy. J Infect Dis. 2008;197(1):126-133. http:// RNA levels in the absence of therapy. J Infect Dis. 2008;197(1):12
dx.doi.org/10.1086/524143, PMid:18171295, PMCid:PMC3466592

36. Hertoghe T, Wajja A, Ntambi L, et al. T cell activation, apoptosis and cytokine dysregulation in the (co)pathogenesis of HIV and pulmonary tuberculosis (TB). Clin Exp Immunol. 2000;122(3):350-357. http://dx.doi.org/10.1046/j.1365Clin Exp Immunol. 2000;122(3):350-357. http://dx.d
2249.2000.01385.x, PMid:11122240, PMCid:PMC1905783

37. Ddo SR, de Cunha RM, Kallas EG, et al. Distribution of naive and memory/effector CD4 + T lymphocytes and expression of CD38 on CD8 + T lymphocytes in AIDS patients with tuberculosis. Braz J Infect Dis. 2003;7(2):161-165. http://dx.doi. org/10.1590/S1413-86702003000200010

38. Orendi JM, Bloem AC, Borleffs JC, et al. Activation and cell cycle antigens in CD4+ and $\mathrm{CD} 8+\mathrm{T}$ cells correlate with plasma human immunodeficiency virus (HIV-1) RNA level in HIV-1 infection. J Infect Dis. 1998;178(5):1279-1287. http://dx.doi. org/10.1086/314451, PMid:9780247

39. Fleury S, de Boer RJ, Rizzardi GP, et al. Limited CD4+ T-cell renewal in early HIV-1 infection: Effect of highly active antiretroviral therapy. Nat Med. 1998;4(7):794801. http://dx.doi.org/10.1038/nm0798-794, PMid:9662370

40. Rodrigues DS, Medeiros EA, Weckx LY, et al. Immunophenotypic characterization of peripheral T lymphocytes in Mycobacterium tuberculosis infection and disease. Clin Exp Immunol. 2002;128(1):149-154. http://dx.doi.org/10.1046/j.13652249.2002.01809.x, PMid:11982602, PMCid:PMC1906372

41. Kolte L, Gaardbo JC, Skogstrand K, et al. Increased levels of regulatory T cells (Tregs) in human immunodeficiency virus-infected patients after 5 years of highly (Tregs) in human immunodeficiency virus-infected patients after 5 years of highly Tregs. Clin Exp Immunol. 2009:155(1):44-52. http://dx.doi.org/10.1111/j.1365Tregs. Clin Exp Immunol. 2009;155(1):44-52. http://dx.d
2249.2008.03803.x, PMid:19016807, PMCid:PMC2665678

42. Tenorio AR, Spritzler J, Martinson J, et al. The effect of aging on T-regulatory cel frequency in HIV infection. Clin Immunol. 2009;130(3):298-303. http://dx.doi. org/10.1016/j.clim.2008.10.001, PMid:19008157, PMCid:PMC2662473

43. Weiss L, Piketty C, Assoumou L, et al. Relationship between regulatory T cells and immune activation in human immunodeficiency virus-infected patients interrupting antiretroviral therapy. PLoS One. 2010;5(7):e11659. http://dx.doi. org/10.1371/journal.pone.0011659, PMid:20657770, PMCid:PMC2908121

44. Hane AA, Thiam D, Cissokho $S$, et al. [Hematologic abnormalities and immunodepression in HIV]. Bull Soc Pathol Exot. 1991;92(3):161-163.

45. Kony SJ, Hane AA, Larouzé B, et al. Tuberculosis-associated severe CD4+ T-lymphocytopenia in HIV-seronegative patients from Dakar. SIDAK Research Group. J Infect. 2000;41(2):167-171. http://dx.doi.org/10.1053/jinf.2000.0721 PMid:11023763

46. Morris L, Martin DJ, Bredell $H$, et al. Human immunodeficiency virus-1 RNA levels and CD4 lymphocyte counts, during treatment for active tuberculosis, in South African patients. J Infect Dis. 2003;187(12):1967-1971. http://dx.doi. South African patients. J Infect Dis.
org/10.1086/375346, PMid:12792875 